\title{
Good workers for good jobs: improving education and workforce systems in the US
}

Harry J Holzer

Correspondence: hjh4@ georgetown.edu Georgetown University, Georgetown, USA

\begin{abstract}
Stagnant earnings and growing inequality in the US labor market reflect both a slowdown in the growth of worker skills and the growing matching of good-paying jobs to skilled workers. Improving the ties between colleges, workforce institutions, and employers would help more workers gain the needed skills. Evaluation evidence shows that training programs linked to employers and good-paying jobs are often cost-effective. Helping more states develop such programs and systems would help raise worker earnings and reduce inequality.

Keywords: Education, Workforce, Good jobs

JEL Codes: J24, J31
\end{abstract}

\section{Introduction}

Among economists, discussions of why the earnings of workers in the U.S. have stagnated over time, especially among disadvantaged populations, generally fit into one of two categories. One focuses primarily on the education and skills of US workers, and how they have failed to keep pace with employer skill needs over time. The other focuses on the quality of jobs, rather than workers, and argues that legal and institutional changes have reduced the pressure on employers to generate high-quality jobs for US workers.

Of course, these two discussions have quite different implications for the policies that are needed to improve workers earnings and reduce inequality. The former emphasizes our need to improve worker skills by raising educational attainment and achievement among US workers, especially among lower-income groups. In contrast, the latter emphasizes the need to pressure employers into raising job quality, mostly by strengthening collective bargaining rights and labor standards (such as minimum wage laws) ${ }^{1}$.

I will argue below that there is some truth to both views. Employers do create good jobs in the US, but they are doing this less than in the past for workers with weak education levels and occupational skills. In particular, workers who lack some kind of postsecondary educational credential or training have increasing difficulty finding good jobs. And too many Americans, especially from low-income backgrounds, fail to earn these credentials and attain these skills. This seems to be true for general educational attainment as well as specific occupational training, and at the middle of the education

(c) 2012 Holzer; licensee Springer. This is an Open Access article distributed under the terms of the Creative Commons Attribution License (http://creativecommons.org/licenses/by/2.0), which permits unrestricted use, distribution, and reproduction in any medium, provided the original work is properly cited. 
and training spectrum (i.e., beyond a high school diploma but below a bachelor's degree) as well as the top.

Accordingly, we need policies that will enable more workers to obtain the skills and credentials that employers seek when creating good jobs. This means not only a stronger educational system, but one in which higher education and workforce development are more effectively integrated and responsive to trends in the labor market, especially sectors where good jobs are being created.

Below I lay out this argument. First I consider trends in labor demand - specifically, where good jobs are being created, and what skills employers need to fill them. Next I consider why the supply of workers with these skills does not always respond to the demand-side trends, as simple labor market models with very elastic supplies of skills (in the long run) suggest they should. I review evidence on education and training programs and practices that seem relatively successful at raising skill levels among the disadvantaged, and also their employment and earnings. Then I discuss a set of policies to generate more such practices, before concluding.

\section{Evidence on jobs and skills}

Are "good jobs" disappearing in the U.S.? In a recent book (Holzer et al. 2011), my coauthors and I analyzed data from several states over the period 1992-2003 in the Longitudinal Employer Household Dynamics (LEHD) program. These micro data, based on the universe of Unemployment Insurance records in a state that are linked to various employer and household surveys at the Census Bureau, are longitudinal both for workers and employers. Consequently, we can calculate a "fixed effect" for each employer and each worker, measuring the average (time-invariant) quality of each, controlling for the other. Our particular interests lay primarily in trends in job quality over time, and in how good jobs were being matched to workers ${ }^{2}$.

Under certain assumptions, interpreting the estimated firm effect as a measure of job quality in any firm, controlling for the skills embodied in their workers, is quite reason$a_{b l e}{ }^{3}$. As is widely known, these premia on average are higher in some industries than others but also vary considerably within industry and geographic region. In some cases, the premia might represent product market rents that are shared by firms with their workers, perhaps because of unionization; in other cases, the premia represent the use "high-road" compensation policies or "high-performance workplace systems" chosen by employers (and sometimes unions) who compete in the labor market on the basis of high worker productivity rather than low wages ${ }^{4}$. In the latter case, the firm premia reflect jobspecific training or compensation practices that elicit different productivity levels among workers in any particular job than in others they have held before or after.

Briefly, the empirical analysis in our book shows that "good jobs" are not disappearing in the U.S. Indeed, during this time period, employment growth in the top quintile of job quality (as defined at the beginning of that period) was quite strong. However, the industrial locus of these jobs was shifting quite dramatically - away from manufacturing and towards a variety of industries such as construction, professional services, finance, health care and even retail trade 5 .

Furthermore, the matching of high-quality workers to high-quality firms has been strengthening over time. This can be seen in Table 1, where we compare the matching 
Table 1 Distribution of employment (percentages) across firm effects quintiles, 1992 versus 2003

\begin{tabular}{|c|c|c|c|c|c|c|c|c|c|c|}
\hline & \multicolumn{5}{|c|}{1993} & \multicolumn{5}{|l|}{2003} \\
\hline & \multicolumn{5}{|c|}{ Firm effects quintile (1=highest) } & \multicolumn{5}{|c|}{ Firm effects quintile ( $1=$ highest) } \\
\hline & 1 & 2 & 3 & 4 & 5 & 1 & 2 & 3 & 4 & 5 \\
\hline \multicolumn{11}{|c|}{ Person Effects Quintile } \\
\hline 1 & 63.6 & 26.3 & 8.0 & 1.9 & 0.3 & 67.7 & 22.4 & 7.6 & 1.8 & 0.6 \\
\hline 2 & 25.8 & 34.1 & 23.2 & 13.0 & 3.9 & 24.9 & 38.6 & 24.4 & 9.9 & 2.2 \\
\hline 3 & 9.3 & 25.7 & 33.7 & 21.9 & 9.4 & 10.5 & 25.6 & 33.7 & 22.4 & 7.8 \\
\hline 4 & 2.4 & 12.6 & 25.5 & 37.9 & 21.6 & 3.7 & 6.8 & 24.2 & 40.0 & 25.4 \\
\hline 5 & 0.2 & 1.6 & 10.2 & 26.8 & 61.1 & 2.4 & 2.5 & 7.8 & 27.2 & 60.1 \\
\hline
\end{tabular}

Note: Rows sum to 100\%. Source: Holzer et al, 2011.

of workers to jobs by quintiles in the person and firm effect distributions in $1992 \mathrm{v}$. 2003. For example, we find that the share of workers in the highest skill quintile filling the top quintile of jobs rose from 64 to 68 percent in just over a decade, while the share of workers in the second quintile filling comparable jobs rose from 34 to 39 percent.

In other words, the ability of less-skilled workers to obtain high-wage jobs has been diminishing, while higher-skilled workers were increasingly getting jobs that paid an employer premium above that dictated by their permanent skills. Even in manufacturing, we found that the drop in employment among less-skilled workers (presumably those doing product assembly and other routine chores) was far greater than among highly-skilled workers (presumably engineers, managers and skilled technicians such as machinists) ${ }^{6}$.

In other words, job quality in the past was, at least to some extent, a substitute for worker skills; but it is increasingly becoming more of a complement to them over time. In a more global and technologically advanced labor market that is also becoming more competitive, fewer employers will pay wage premia as a way of sharing product market rents $^{7}$. Instead, employers will only choose "high-road" compensation policies if such compensation can be offset by higher productivity, and if worker skill levels are high enough to merit further investments by these employers (Holzer et al., 2011). The analysis also implies a growing level of inequality between higher- and less-skilled workers, unless the average levels of skill grow sufficiently and are widely enough distributed to counteract this growing complementarity of worker and job quality.

Of course, the estimated "person effect" does not indicate exactly which skills are needed to obtain these high-quality jobs, though we can make some inferences from the sectors in which high-quality job growth is observed, and other data on what constitutes high, middle and low-paid jobs in each sector. For instance, the highest skilled workers in health care are no doubt physicians, and in the professional services are likely those with advanced professional degrees (e.g., lawyers, engineers, accountants) in a range of fields; the middle-skilled workers are likely to be craftsmen in construction, technicians and nurses in health care, managers in retail trade, and skilled technicians (like machinists and precision welders) in manufacturing. If true, this suggests that a mix of general education and occupation-specific skills are still rewarded with relatively high pay and strong demand in the labor market.

Importantly, the data do not suggest a disappearing middle of the labor market in this time period, as good jobs are not rapidly dwindling for workers in the middle of the 
skill range (as defined above). In a series of recent papers, David Autor (2010), along with various coauthors (e.g., Autor and Acemoglu, 2010 and 2012) have argued that middle-wage and middle-skill jobs have been growing less rapidly than those at higher and lower wages; this occurs because the middle-level jobs tend to rely more on routine task-performance, which is easily replaced by digital technologies, whereas higher- and lower-skilled jobs require more complex analytical skills or social interactions respectively that are less easily replaced.

But a closer look at these data (Holzer, 2010) shows that the decline in middle-skill jobs over time is somewhat uneven across occupation or industrial categories, and its magnitude depends to some extent on how we define middle-skill jobs. For instance, much of Autor's analysis is based on average occupational wages as of 1980, when a relatively high percentage of middle-wage jobs were in production and clerical jobs, often in manufacturing and/or other highly unionized industries, which paid well for workers with high school or less education. But a look at occupational distributions over time in Table 2 shows that declining employment among production/operator and clerical workers accounts for virtually all of the observed decline over time in the 1digit middle-skill occupations (defined as those between the professional/managerial and the various service occupations $)^{8}$.

In other words, the declining middle is accounted for mostly by the disappearance of good-paying, routine-work jobs for high school graduates and dropouts, and not by declining demand for workers with various kinds of postsecondary education or training short of a bachelor's degree (BA). Indeed, Autor (2010) shows that returns to workers with "some college" have been growing relative to those with high school or less (albeit not as much as for those with BA degrees or higher), which would not occur if demand for middle levels of skill defined in this way were truly collapsing 9 .

Furthermore, data on task performance by occupational category in Autor and Handel (2009) show that the average analytical content of many such middle-skill jobs is now relatively high, and cannot be considered routine in nature; also, their relative wages (as well as employment) have not declined over time ${ }^{10}$. An analysis of wage and employment trends within more narrowly defined occupational and industrial groups, as well as of relative wages for those with some college but less than a bachelor's degree, confirm that demand growth in many middle-skill jobs - again defined as those

Table 2 Employment shares by occupation, 1979 and 2007

\begin{tabular}{lll}
\hline & $\mathbf{1 9 7 9}$ & $\mathbf{2 0 0 7}$ \\
\hline Managers & 9.8 & 4.4 \\
Professionals & 11.7 & 15.7 \\
Technicians & 3.1 & 3.5 \\
Sales & 10.0 & 11.4 \\
Office and Admin. & 17.3 & 14.0 \\
Production, Craft and Repair & 12.7 & 10.1 \\
Operators, fabricators and laborers & 19.2 & 11.9 \\
Protective Service & 1.5 & 2.2 \\
Food Pre, Building and grounds, Cleaning & 7.4 & 8.8 \\
Personal care and Personal Services & 5.0 & 6.8 \\
\hline
\end{tabular}

Source: Autor and Handel (2009). 
requiring some postsecondary education or training below a four-year diploma - has been relatively strong ${ }^{11}$.

In sum, Acemoglu and Autor (2012, pp. 460-61) write that "...we do not forecast the demise of all or even most middle skill jobs soon," and stress that a ". . .rapidly growing category of relatively well-remunerated, middle-skill occupations" is still available that often requires "one or two years of postsecondary vocational training" short of a BA. All of their work is therefore fully consistent with the data above showing a growing complementarity over time between personal skills and firm wage premia, and strong labor market demand relative to supply for workers with these skills, even in jobs that do not require four-year college or advanced degrees.

And, while the Great Recession has strongly hurt employment in some middle-skill occupations (especially in manufacturing and construction), it is not clear that all of these declines are permanent ${ }^{12}$. It is even possible that the availability of such "good jobs" in the U.S. would grow if more employers felt that they were easier to fill with good workers, and that state and local economic development efforts might be more successful if accompanied by effective policies to increase local human capital (Bartik, 2009; McGahey and Vey, 2008) ${ }^{13}$.

Overall, then, the data suggest that demand for skills in the labor market remains relatively high, in both middle- and highly-skilled occupational categories, and that good-paying jobs are available for workers with these skills. Yet the supply of workers with the relevant postsecondary credentials for good-paying jobs has apparently not kept pace with growing demand, as Goldin and Katz emphasize; and it is unlikely to do so in the coming decades, given demographic projections ${ }^{14}$. Despite strong labor market incentives to do so, the supply of workers with the relevant skills seems less responsive to labor demand trends (i.e., less elastic) than we might have believed, even in the long run, and especially among disadvantaged students.

Why is this so? For one thing, dropout and noncompletion rates remain very high not only at the high school level, but also at two-year and four-year colleges. Noncompletion rates are especially high at two-year and non-elite four-year colleges, among minorities, and among low-income students - particularly those with Pell grants ${ }^{15}$. And, even among those who complete credentials (including certificates as well as AA and BA degrees), the variance in their subsequent earnings is very high, suggesting that not all have skills that are well matched to sectors and occupations with good-paying jobs and strong demand (Jacobson and Mokher, 2009; Altonji et al., 2012).

Of course, there are many likely reasons for the high noncompletion rates we observe. They include poor academic preparation in the K-12 years; the ineffectiveness of college remediation classes; the conflicting demands of school, work and childrearing among young parents; the rising costs of higher education for those who are liquidity constrained, and the limited resources that are available in non-selective institutions; and a lack of supportive services for those attending college (Kemple and Rouse, 2009; Brock, 2010; Bound et al., 2009; Haskins et al., 2009). And the high variance in returns to credentials likely reflects the limited skills and preferences of students for obtaining credentials in fields that are well-paid (such as those involving technical skills that require students to complete substantial coursework in math or science), compounded by their own uncertainty and the sequential nature by which they make their (often irrevocable) schooling choices (Altonji et al., op. cit.) ${ }^{16}$. 
But a disconnect between American high schools and colleges, on the one hand, and the institutions of the labor market, on the other, also likely contributes to these outcomes. For instance, high school dropout rates are high at least partly because students often perceive no relevance to their future job prospects of what they learn, and have little motivation to succeed (Center for Education Policy, 2012). A large body of evidence (summarized in Lerman, 2007) suggests that contextual learning can improve these incentives, and that paid work experience in the short term can be an especially strong motivator among low-income youth ${ }^{17}$.

High-quality career and technical education (CTE), including apprenticeships and other school-to-career models, can provide the context and the motivation for such learning, as Ryan (2001) and Silverberg (2004) have shown. Yet we have largely failed to develop a range of high-quality CTE options, which could prepare students for postsecondary education as well as the job market, at least partly due to our fear of "tracking" and our use of test scores as the only legitimate measures of academic "achievement" (Hoffman, 2011; Symonds et al., 2011).

In general, low-income students lack a great deal of information about the world of higher education (Long, 2010), and apparently about the labor market as well ${ }^{18}$. At community and non-elite four year colleges, remedial classes are separate and distinct from academic or occupational training courses; so many students often perceive little relevance of their remedial classes to their ultimate coursework. Students obtain relatively little in the way of career counseling and directed study at most community colleges, of the type that appears to be quite effective at raising completion rates and subsequent earnings at proprietary training schools (Rosenbaum, 2001); as a result, their knowledge of and preparation for high-demand and well-paying jobs in the labor market, and of which courses of study might help them achieve higher earnings, is very limited.

Indeed, such counseling and labor market information more generally are provided at the One-Stop offices funded by the Labor Department ${ }^{19}$. But few college students receive such services or ever enter these offices, while very little funding for long-term training is provided for those who do enter One-Stop offices. More broadly, while funding for Pell grants has risen very dramatically in the past few years, funding for the Workforce Investment Act (WIA) and the services it provides has shrunken just as dramatically over the past three decades (Holzer, 2013) ${ }^{20}$. And relatively little has been done to encourage more integration on the ground between the services offered by our workforce agencies and our institutions of higher education.

And the colleges themselves have little incentive to expand instructional capacity in areas of strong labor market demand ${ }^{21}$. Community college administrators will often note that they receive the same subsidy from the state per student regardless of the courses in which students enroll, though the costs of equipment and instructor salaries in many technical areas or in high-demand areas (like health care) are relatively high; and subsidies are also independent of rates of student success or completion.

In short, the supply of workers with the general or occupational-specific skills to obtain good jobs in the U.S. labor market would likely be more responsive to demandside trends if postsecondary and higher education in the U.S. were more effectively integrated with workforce programs and services, and if information on and experience in the labor market were more broadly available to American students. 


\section{Are efforts to improve labor market skills effective?}

The argument above, that the skills of American workers can be made more responsive to employer needs and demand-side trends in the labor market, becomes more compelling if evidence on programs and policies that aim to provide such skills cost-effectively can be provided. Fortunately, a wide body of such evidence now exists and can be used to guide policy in this area. The strongest evidence comes from experimental studies, using randomized control trials (RCT), though some non-experimental studies provide important evidence as well, as noted below ${ }^{22}$.

For instance, strong evidence on the cost-effectiveness of high-quality CTE programs can be found in an evaluation of the Career Academies (Kemple, 2008) using RCT. The academies are schools within more comprehensive high schools that train students for careers in specific sectors, and often those with good-paying jobs and strong employment growth (like health care, IT and financial services). Students take classes in the broader high school but also in the academies, and they receive work experience during the summer and academic year as well.

The evaluation shows little effect of Career Academies on the academic outcomes of participants, though there was some evidence of reduced dropout rates early on. Interestingly, there is also no evidence of negative impacts on postsecondary educational enrollments or attainments - which one might expect if the academies were "tracking" students away from college. Instead, the evaluation showed strong positive impacts of Career Academies on the employment and earnings of students, especially for at-risk young men. And these positive impacts persist for up to eight years after random assignment of students into the treatment and control groups, and even after large numbers have changed jobs and careers. Presumably, the early exposure to and preparation of these students for the labor market gave them a set of skills that were portable across jobs and economic sectors over time.

Another important development has been the programmatic and evaluation work on sectoral training programs for the disadvantaged. In these programs, intermediaries bring together workers, training providers (which may or may not be community colleges) and employers who pay well and have job openings in high-demand sectors such as health care and IT (Conway et al., 2012). By developing detailed knowledge of these sectors and of employer needs, the intermediaries make sure that workers receive the training and have the characteristics that the employers will value, thus raising the probabilities that the workers will be hired after completing the training and be wellcompensated.

A recent RCT evaluation of three sectoral training programs by PPV (Maguire et al., 2010) showed strong impacts on the earnings of disadvantaged workers. As much as two years after random assignment, earnings of the treatment group exceeded those of controls by roughly $\$ 4000^{23}$. In a similar RCT evaluation of another sectoral program for youth (called Year-Up), Roder and Elliott (2011) found impacts of similar magnitudes on the relative earnings of program trainees ${ }^{24}$.

Of course, many important questions remain about these findings. Will the estimated impacts persist over longer periods of time - especially after workers change jobs or even industries? Will demand persist over time in these sectors, and if not, will the impacts of such specific training diminish even faster? Can these positive impacts be replicated in other and newer settings, and can they be brought to scale ${ }^{25}$ And to what 
extent do the impacts represent social as opposed to only private gains, if net new employment in these good-paying jobs is not being generated? ${ }^{26}$ While these questions are very important, the positive impacts found so far are very encouraging, as they are substantially larger than impact estimates generated by federally-funded training more generally $^{27}$.

Some other evidence has recently been generated in RCT studies of efforts at community colleges to improve educational outcomes among disadvantaged students. Some of these, such as performance-based financial aid, mandatory counseling and the use of "learning communities" at colleges (Brock, 2010), are quite general in nature and do not necessarily strengthen connections between these students and the labor market.

But some non-experimental evidence at least suggests the usefulness of combining education with specific occupational training or work experience. In one important effort, the Integrated Basic Education and Skills Training (I-BEST) program in the state of Washington, has redesigned remedial education by integrating remediation into occupational training classes. Instead of having separate remediation and training classes, each training class now has two instructors, with one each focusing on remediation and skills instruction. Because all remediation is now linked to what is actually needed for the skills training, and because the former is contextualized within the latter, it is quite possible that the remediation will be more effective. Indeed, the student outcomes apparently generated by I-BEST recently in a matching study by Zeidenberg et al. (2010) are quite positive and suggest strong possible impacts. Several states are now trying to replicate I-BEST and adapt it to their own disadvantaged populations ${ }^{28}$.

Incumbent worker and apprenticeship training provide other examples in which training for relatively less-educated workers can be combined with work experience in a manner that tailors the training to the needs of employers and the demand side of the labor market. Incumbent worker training programs, often funded by states, provide financial assistance to employers to train workers, usually at the entry level, for the skills they need in their current or possible future jobs. The partial public support for this training is based on the assumption that employers will not provide it on their own, either because the training is too general or due to other market failures (Acemoglu and Pischke, 1998; Lerman et al., 2004) ${ }^{29}$. A quasi-experimental evaluation of an incumbent worker training grants program for firms in Michigan by Holzer et al. (1993) showed positive impacts on worker performance, and non-experimental evidence by Hollenbeck (2008) on a range of state programs suggests positive impacts on worker outcomes as well ${ }^{30}$. Similarly, Lerman (2010) has reviewed some nonexperimental evidence of apprenticeship training that suggest strong positive impacts on subsequent earnings and employment of these workers, as do the papers in Neumark (2007) for a variety of "school-to-work" programs in the US ${ }^{31}$. A more recent study by Reed et al. (2012) on apprenticeships in several states also suggests strong positive impacts.

Finally, some programs that focus on disadvantaged youth also suggest the potentially positive effects of providing education or training in ways that are more closely linked to work experience in the labor market. For instance, a demonstration project in the late 1970s known as the Youth Incentive Entitlement Pilot Project (YIEPP) guaranteed a minimum wage summer or part-time job for youth who remained in high school in several cities around the country. While the program was discontinued before any post-program impacts could be estimated, the in-program effects in this RCT study 
were quite substantial - as the enormous employment gaps between white and black youth in those cities were eliminated (Heinrich and Holzer, 2011). Also, the Youth Opportunity program created by the Clinton Administration in 2000 funded youth education and employment centers in 36 low-income neighborhoods, from which all youth in those neighborhoods could be tracked and frequently referred to available services. Estimated impacts of the program on both education and employment outcomes of the youth were mostly positive, suggesting that larger-scale systemic approaches could be used effectively to improve these outcomes ${ }^{32}$.

Of course, the implications for all of these programs and studies for policy depend heavily on whether or not estimated impacts will survive over the long-run and whether they can be replicated at larger scale. While the answers to these questions remain largely unknown, some important efforts to implement them at scale have been undertaken and deserve some mention.

For instance, as many as 30 states have implemented workforce development systems that are at least partially sectoral in nature in the past several years (Center for Best Practices, 2009; Edelman et al, 2011). In these states, partnerships have been developed between workforce agencies, employer associations in high-demand/high-paying industries, and training providers to develop sectoral training programs on a large scale. Those who operate these systems rely heavily on available data on labor market developments and openings to guide their planning. Challenges remain in many cases, especially for providing sustainable sources of funding, but at least the ambition and scale of these efforts is noteworthy.

Some other efforts, such as the National Fund for Workforce Solutions, have similarly tried to build sectoral workforce systems at the level of cities, metropolitan areas or substate regions, usually with support from the federal government or groups of private foundations ${ }^{33}$. And several federal programs and private foundations have funded efforts that focus primarily on community colleges, to improve student outcomes in general but also their ties to the labor market more specifically (Holzer and Nightingale, 2009). The largest federal effort, the Trade Adjustment Assistance Community College and Career Training program (TAACCCT), provides competitive grants to community colleges around the country to develop training programs geared to local labor market trends; while major foundation efforts, such as Achieving the Dream and Breaking Through, fund a range of community college effort around the country in key states ${ }^{34}$.

While we have no rigorous evidence yet of any impacts from these programs, the attempts to date to implement labor market oriented programs at such scale are important and certainly require further study ${ }^{35}$.

\section{Funding more effective education and workforce systems: a proposal}

I believe that the efforts to date to develop more effective and better integrated education and workforce systems at the state level, that are better tied to high-demand and good-paying jobs in the labor market, are very promising and deserve more support and more analysis. Accordingly, I recently proposed the creation of a new competitive grant program at the federal level to fund such efforts (Holzer, 2011) ${ }^{36}$.

The program would be jointly administered by the US Departments of Education and Labor. It would be designed to supplement activities and services currently funded 
through WIA, but with much more of a focus on helping states and regions build integrated education and workforce systems in response to local job market conditions ${ }^{37}$. In some ways, it would be modeled on the "Race to the Top" competitive grants administered to the states by the U.S. Department of Education, which were large enough in magnitude to have a fairly large impact on state planning and policy in their K-12 systems.

States and regions would be encouraged to apply for funds for education and workforce development systems that are more closely tied to good jobs and local labor demand trends. Grants would fund both planning and implementation of these systems, and would be potentially renewable if evaluations (based on rigorous methods) indicated that positive impacts had been generated at significant scale.

In addition to the building of key institutional partnerships between education and workforce agencies, industry associations, and training providers, the grants could also be used to directly finance a range of services for mostly low-income students and workers, that are not well-financed today through WIA, Pell grants or other funding sources. These services might include:

- Tuition payments for individuals and/or training providers who are not currently eligible for Pell funding;

- Stipends for paid work experience programs under apprenticeships, internships, and other "learning while earning" models;

- Support services for low-income students, like performance-based scholarships and funding for child care;

- Subsidies to strengthen the incentives community colleges face for training more people for high-demand jobs ${ }^{38}$; and

- Incentives and institutional supports for firms that create good-paying jobs for the disadvantaged, including technical assistance and subsidies or tax credits ${ }^{39}$.

Among the criteria by which applications would be judged would be whether or not programs and systems focus on the disadvantaged; to what extent the proposal identifies and involves the right partners, including secondary and postsecondary educational institutions and workforce agencies as well as employer associations; the extent to which existing activities are built on and funding sources are leveraged, and also whether sustainable sources of funding have been identified; the extent to which plans have a solid research and evidence base, and also the quality of evaluation plans proposed for afterwards. States would also need to indicate how they would use various sources of labor market data, including survey and administrative data, to better inform their education and workforce systems about current and recent trends in labor demand ${ }^{40}$.

One possible problem with this proposal is that it relies quite heavily on meeting occupation- and industry-specific demand that now exists but that might shift over time in unanticipated ways. Proposals should therefore be careful to show that general worker skills would be enhanced by these efforts, at least some of which should be portable across employers and even sectors; and that plans are nimble enough so that they can respond to such demand shifts, especially by engaging employers and industry associations in the new sectors to which demand might be shifting and where labor markets are tight. 
Some other potential problems might impede the overall effectiveness of this policy proposal - including our limited knowledge to date on how to scale up successful efforts, the difficulty we often have engaging large numbers of employers in publicly funded efforts, the potential for windfalls and free ridership among employers who might already finance some of this training, possible fadeout of positive impacts over time, and the general difficulty with trying to end policy "silos" and encourage crossagency collaboration at the state and local levels. In the fiscally austere future which we will likely face for many years to come, new sources of public funding might be hard to come by - especially for workforce efforts that have already shrunk so dramatically over the past three decades.

Because of these considerations, building effective public and private infrastructures at the state and local levels that better align worker skills with local demand and bringing them to scale will be quite challenging. Any federal grants program to encourage the development of this infrastructure should carefully consider evidence on what has been successfully accomplished in the thirty or so states that have undertaken some such polices to date, and should explicitly reward efforts to build on and replicate the state programs that have achieved and maintained scale over time while being flexible enough to respond to ongoing shifts in demand.

If this is done, the potential exists not only to generate effective policies where social gains substantially exceed costs (Holzer, 2011), but also to gain ongoing political support for them, especially from local business communities and their workers who might benefit from this idea. For employers who currently have difficulty finding skilled workers to meet their needs, and from the potential workers themselves, political support might be substantial, even in the current austere fiscal environment.

\section{Conclusion}

Labor economists continue to debate the extent to which growing labor market inequality and stagnant earnings, especially among disadvantaged Americans, reflects trends in worker skills as opposed to job quality. But recent evidence suggests that these two factors are more closely related to one another than in the past. Our labor market continues to create good jobs, but increasingly they are limited to workers with an appropriate set of general and/or occupation-specific skills.

And the growth in the relevant skills of American workers to fill these jobs has apparently not kept pace with growing demand. This is likely true in the middle of the skills spectrum, where workers need some postsecondary education or training beyond high school but less than a bachelor's degree, as well as at the top (BA or higher). There are many reasons for why this is true; but the disconnect between our education and workforce institutions, and the lack of information about and experience in the workforce for so many students, no doubt contributes importantly to these skill deficiencies.

Accordingly, I argue above that we need to better integrate our education and workforce systems, and to make sure that both are more closely aligned at the state and regional levels with trends in labor demand. Students and workers need better information about where good jobs can be found and where such employment appears to be growing as they make their education and training decisions. Appropriate work 
experience and engagement with employers in these sectors can be an important complement to education and training.

A variety of education and training programs and practices now exist that better align education and training with labor demand and employers, and a body of rigorous evaluation evidence suggests that these programs are quite cost-effective at raising skills and earnings among the disadvantaged. I therefore propose a new federal grants program to encourage states and regions to better integrate their public education and workforce systems, and to align them more closely with trends in labor demand. Providing supports for employers who provide good jobs could also be helpful.

The limitations of this approach are fairly clear. Whether our best models can be replicated and brought to appropriate scale remains uncertain. As noted above, labor demand can shift in ways that are not well anticipated, and workers need to be able to move across sectors of the economy when this occurs. The appropriate balance between general and specific occupational or sectoral training needs to be found. Opportunities for students to gain occupational training must also not discourage them from obtaining higher education; in other words, career and technical education in the U.S. must become more of a complement, and less of a substitute, for postsecondary training ${ }^{41}$.

The effects of the Great Recession of 2007-09, and the very slow recovery of our labor markets from that downturn, must also be addressed. During this slow recovery, demand for labor will be limited in many or most sectors; and the extent to which employment is some areas, such as construction and manufacturing, will recover over time is not yet clear. Whether demand for skilled labor, especially in the middle of the skills distribution, will remain permanently depressed is also open to question.

On the other hand, workers with more postsecondary education and training suffer less unemployment, even now, than those with less such training. Over the longer term, more effective education and training should help reduce inequality and raise earnings potential, especially among disadvantaged populations. Those who continue to have low skills and earn low wages will still need other kinds of income supplements, such as the Earned Income Tax Credit and child care assistance. And how all of this can be provided in the austere fiscal climate that will prevail over the coming years and decades remains a question.

Thus, the proposals above are certainly not panaceas for all of the problems of disadvantaged American workers. On the other hand, they would almost certainly help.

\section{Endnotes}

${ }^{1}$ See Autor et al. (2008) and Goldin and Katz (2008) for the argument that the supply of workers with higher education since the 1970s has failed to keep pace with growing demand, thus contributing importantly to labor market inequality. For an alternative view, see Card and Dinardo (2007) or Mishel et al. (2010). The extremely high growth of earnings among the top $1 \%$ of earners (Saez: Striking It Richer: The Evolution of Top Incomes in the United States, unpublished) and the growth of inequality over time within education groups (Lemieux, 2006) are somewhat separate issues. For an analysis that stresses both worker skills and management differences across firms see Bloom and Van Reenen (2010). 
${ }^{2}$ Our data cover 12 states over this time period, and the states are fairly representative of the U.S. in terms of demographic characteristics of workers and industry structure of the economy. See Chapters 1 and 2 in Holzer et al. (2011) for more details. The appendix to Chapter 2 describes the exact equations estimated and methods used to estimate them in some detail, which were generated by Abowd et al. (2002, 2006). Equations were estimated for the ln (annualized earnings) across person-years that included fixed effects for all workers and firms, plus year dummies and time-varying characteristics of both firms and workers (such as firm size and worker experience in any year) and a range of interactions between them. Given the extraordinary sizes of these datasets, which essentially contain the universe of workers and firms in any state over a 12-year period, computational demands required that the equations be estimated in an iterative manner, beginning with workers in the largest 2000 firms, and with some estimated parameters from these initial equations then used to compute fixed effect estimates for other firms and workers.

${ }^{3}$ Interpreting the fixed firm effects as job quality does not require worker mobility and matching across firms to be completely random, which would clearly not be true. Instead, it assumes such mobility and matching to be approximately random, conditional on the very extensive set of person effects and time-varying characteristics of firms and workers (plus interactions) included in the estimated model. This assumption might be violated, for example, by major changes in firm quality over time or by the existence of important firm-worker interactions. But Abowd et al. (op. cit.) argue that any such biases are likely to be minor, and that the assumption of conditional randomness of the matching process is quite reasonable.

${ }^{4}$ The notion that some employers choose high-performance workplace practices is consistent with various "efficiency wage" theories of the labor market. For a general description of personnel practices in a variety of sectors, and how firms in the same industries make very different choices about compensation and training, see Appelbaum et al. (2003). For a review of evidence on firm wage premia, and their variance even within industry and locality, see Abowd and Kramarz (1999).

${ }^{5}$ Our results show that the share of top quintile jobs in manufacturing declined by over a third in our 11-year period - from about 37 to 24 percent of the total. Its share of jobs in the second quintile declined from 26 to 19 percent. Evidence that higherquality jobs are now being created even in retail trade can be found in Cardiff et al. (The Spread of Modern Retail and Jobs for Service, unpublished).

${ }^{6}$ The share of workers in the top quintile of skills employed in manufacturing fell from 28 to 25 percent in this period. In contrast, the share of the bottom two quintiles fell from 18 to 8 percent and 10 to 4 percent respectively.

${ }^{7}$ Hirsch (2008) similarly argues that increased product market competition, from globalization and deregulation policies, has contributed somewhat to the decline of unionized jobs over the past several decades in the U.S.

${ }^{8}$ According to Table 2, the share of employment in the middle-skill occupations dropped from 62 to 51 percent, with 10 percentage points accounted for by production/operator jobs and another 3 points by clerical jobs.

${ }^{9}$ The fact that so many workers in the "some college" category have not completed a credential of any kind no doubt biases this estimated return downwards as a measure of returns to postsecondary credentials. 
${ }^{10}$ For instance, Table 3 of Autor and Handel (2009) shows that construction/repair jobs score quite high on reading, math and problem-solving tasks; and that technician/ sales jobs score quite high on management and problem-solving tasks. The remaining clerical and production jobs also score reasonably high on these tasks. Trends in relative wages across occupational categories can be found in Acemoglu and Autor, 2010.

${ }^{11}$ According to Holzer and Lerman (2007), both relative wages and employment in the construction crafts, health technology and nursing occupations, and a range of installation/maintenance/repair jobs rose between the mid-1980s and 2006.

${ }^{12}$ See Autor (2010) and Jaimovich and Siu (2012) for discussions of middle-skill employment declines during this recession. The latter argues that "jobless recoveries" are mostly caused by ongoing employment shrinkages in middle-skill jobs in recovery periods, though whether this will continue to be true as the recovery continues is open to question. To date, nearly one-fifth of the jobs lost in manufacturing during the recession have been recovered, while virtually none of those lost in construction have returned. But construction is likely to rebound to its long-term trend once the U.S. housing stock has returned to its own long-term equilibrium, while at least some availability of such "good jobs" in the U.S. would grow if more employers felt that they were easier to fill with good workers, and that state and local economic development efforts might be more successful if accompanied by effective policies to increase local human capital (Bartik, 2009; McGahey and Vey, 2008).

${ }^{13}$ For instance, the Siemens Corporation has built a new gas turbine engine manufacturing plant in North Carolina, but they made this decision only after arranging for training programs to be set up for skilled employees at the University of North Carolina.

${ }^{14}$ Projections of labor supply presented in The Aspen Institute (2003) suggest that, as Baby Boomers retire and are replaced by immigrants during the next decade, workers with some college as well as a BA or higher will shrink substantially as shares of the labor force. Though retirements are proceeding somewhat more slowly than originally projected, and immigrant education levels might vary over time in response to economic conditions or policy changes, the qualitative predictions are still likely to hold.

${ }^{15}$ See Heckman and Lafontaine (2007) for evidence that roughly a fourth of US students fail to complete high school. Evidence on college completion rates for Pell recipients and low-income students can be found in Complete College America (2012).

${ }^{16}$ There has been some controversy over the extent to which jobs in the fields of science, technology, engineering and math (or "STEM") pay better than those with comparable level $\mathrm{s}$ of education and show growth in demand outpacing supply. For discussions of these issues and the most recent evidence see Carnevale et al. (2011) and Langdon et al. (2012).

${ }^{17}$ While it is at least possible that working during school can reduce academic performance in high school (e.g., Stinebrickner and Stinebrickner, 2003), most evidence suggests that modest amounts of work effort do not do so. Most of these studies also do not separate general work experience from that linked to career and technical education.

${ }^{18}$ This argument is made forcefully by Jacobson and Mokher, op. cit., and by Furchtgott-Roth et al. (2009).

${ }^{19}$ See the various papers in Besharov and Cottingham (2011) for descriptions of the services funded by WIA and provided in One-Stop offices. These include "core" 
services, which mostly consist of limited job search assistance, and "intensive" services such as career counseling and testing, before workers can receive any training.

${ }^{20}$ Holzer (2013) calculates that funding for most WIA programs has diminished by about three-fourths in real terms since 1980, and by much more relative to the size of the economy. Federal spending on Pell grants has risen from about $\$ 10 \mathrm{~B}$ in fiscal year 2000 to \$35B in 2011.

${ }^{21}$ Bound et al. (2009) argue that course capacity constraints at non-flagship colleges and universities, often linked to limited resources, contribute to delays in college completion that likely also reduce completion rates.

${ }^{22}$ I use the term "nonexperimental" to refer to the broad range of regression and matching methods that use observable characteristics to control for differences in the quality of those receiving and not receiving the specified treatment. Matching methods have, under certain circumstances, generated some credible estimates of impacts in the literature that evaluates job training programs, which do not differ greatly from experimental estimates (e.g., Milimet et al., 2007; Imbens and Wooldridge, 2009). This is particularly true when evaluations can match individuals in treatment and controls groups based on multiple years of preprogram earnings history and on work in particular local labor markets. The nonexperimental studies cited below generally fall within the range of those considered credible by these criteria.

${ }^{23}$ The three programs evaluated were the Jewish Vocational Service (Boston), Per Scholas (New York) and the Wisconsin Regional Training Partnership (Milwaukee). Costs per participant were somewhat difficult to gauge, especially given differences across sites in how work experience was paid for, but some estimates suggest costs of about $\$ 6000$ per trainee (Holzer, 2011).

${ }^{24}$ Year Up provides training of youth with at least a GED or high school diploma for jobs in information technology (IT) or management.

${ }^{25} \mathrm{An}$ earlier RCT evaluation of a sectoral program, the Center for Employment Training (CET) in San Jose, showed strong impacts on participant earnings in its initial site but these failed to be replicated in an RCT study of other sites (Miller et al., 2005).

${ }^{26}$ If good-paying jobs are limited in quantity, then such jobs might be rationed across those with the appropriate skills, implying that the newly trained workers might displace others with similar skills from these jobs. In this case, the social returns to training might fall short of private returns to program participants. Such rationing is more likely to occur in the short-run and in specific local labor markets than more generally. Also, the positive impacts in the PPV evaluation study seem to accrue to disadvantaged workers with reasonably good basic skills and work experience, rather than the leastskilled and hardest-to-employ in these groups.

${ }^{27}$ See Bloom et al. (1997) for RCT evidence on the impacts of training under the Job Training Partnership Act (JTPA), which preceded WIA. Credible non-experimental evidence on WIA impacts can be found in Heinrich et al. (2009), while the general costeffectiveness of WIA is discussed in Heinrich and King (2010).

${ }^{28}$ In Washington, a large proportion of I-BEST participants are immigrants with limited English proficiency, rather than the native-born disadvantaged.

${ }^{29}$ As is well known among labor economists, employers will be reluctant to pay for general training because the workers in whom they invest could leave the firm at any point. Market failures that might also impede firm investments in worker training 
include imperfect or asymmetric information about worker skills and gains from training, liquidity constraints for the firm, and downward wage rigidities

${ }^{30}$ In the study by Holzer et al., outcomes at small manufacturing firms that received training grants from the state of Michigan were compared to those of firm applicants that met the program criteria but did not receive such funding because the allocated funds had already been spent on a first-come, first-serve basis.

${ }^{31}$ See also Bassi and Ludwig (2000) for a discussion of firm willingness to provide apprenticeships and other forms of on-the-job training.

${ }^{32}$ See Decision Information Research Inc (2008). This study compares education and employment outcomes in the $36 \mathrm{YO}$ sites to a comparison sample of low-income neighborhoods with similar demographics and employment rates in 2000.

${ }^{33}$ The National Fund is supported by several national foundations and has funded sectoral training programs in over 30 cities and regions around the country. Other sources of support for such efforts include the Workforce Innovation in Regional Economic Development (WIRED) grants from the U.S. Department of Labor in the second Bush Administration.

${ }^{34}$ TAACCCT is an outgrowth of the Obama Administration's proposed American Graduation Initiative in 2009, though the former is funded at much lower levels than originally proposed under the latter.

${ }^{35}$ Achieving the Dream programs, funded by the Lumina Foundation (among others), have begun to be rigorously evaluated (Rutschow et al., 2011), but no major impacts on student educational outcomes have been found to date.

${ }^{36}$ Similar ideas have appeared in other proposed legislative vehicles, such as the SECTORS Act, which passed the House of Representatives in 2010.

${ }^{37}$ Until recently, states have retained about 15 percent of WIA funds distributed to localities that could be used to fund such efforts, though the future availability of such funds is in doubt. The Workforce Innovation funds under WIA that have recently been administered by the U.S. Department of Labor provide some funding to states for such efforts as well.

${ }^{38}$ Performance measures for programs can sometimes generate perverse incentives for local training providers (Barnow and Smith, 2004). For instance, paying colleges according to completion rates could induce them to lower academic standards, while paying for job placement could lead to "cream-skimming" among applicants.

${ }^{39}$ Technical assistance to high-paying firms could be modeled on the federal Manufacturing Extension Partnership for small manufacturers, but perhaps with more of an emphasis on incumbent worker skill development. Tax credits could also be provided for firms that generate skilled jobs that particularly contribute to local economic development. See Bartik (2010). Osterman and Shulman (2011) argue that unionization and various labor market regulations, such as higher minimum wage requirements, also incent more employers to create higher performance workplace systems to offset their higher labor costs, though clearly these methods also create the potential for some employment losses in relatively competitive product and labor markets.

${ }^{40}$ State-level administrative data on education and employment outcomes are increasingly being assembled and made available to researchers or practitioners, especially with support from the US Departments of Education (through its State Longitudinal Data Systems, or SLDS, program) and Labor (through its Workforce Data Quality 
Initiative, or WDQI). Real-time data on job vacancies nationwide are also available through a program jointly run by the National Association of State Workforce Agencies (NASWA) and the DirectEmployers Association.

${ }^{41}$ Evidence on the relative returns to general and occupational training appear in Malamud and Pop-Eleches (2010) and Hanushek et al. (2011).

\section{Competing interests}

The IZA Journal of Labor Policy is committed to the IZA Guiding Principles of Research Integrity. The author declares that he has observed these principles.

\section{Acknowledgements}

I would like to thank Fredrik Andersson, David Neumark (the IZA Journal of Labor Policy handling editor) and two anonymous referees for helpful comments on an early draft of the paper.

Responsible Editor: David Neumark

Received: 30 May 2012 Accepted: 23 August 2012

Published: 6 November 2012

\section{References}

Abowd J, Kramarz F (1999) The Analysis of Labor Markets Using Matched Employer-Employee Data. In: Orley A, David C (eds) Handbook of Labor Economics, 3Bth edn., Amsterdam

Abowd J, Lengermann P, McKinney K (2002) The Measurement of Human Capital in the US Economy. LEHD Technical Paper No. TP-2002-09.US Bureau of the Census

Abowd J, Stevens B, Vilhuber L, Andersson F, McKinney K, Roemer M, Woodock S (2006) The LEHD Infrastructure Files and the Creation of the Quarterly Workforce Indicators. LEHD Technical Paper No.TP-2006-01.US Bureau of the Census

Acemoglu D, Autor D (2010) Skills, Tasks and Technologies: Implications for Employment and Earnings. In: Ashenfelter O, Card D (eds) Handbook of Labor Economics, 4Bth edn. Amsterdam

Acemoglu D, Autor D (2012) What Doe Human Capital Do? A Review of Goldin and Katz's Book The Race between Education and Technology. J Econ Lit 50(2):426-63

Acemoglu D, Pischke S (1998) Why Do Firms Train? Theory and Evidence. The Quarterly Journal of Economics 113(1):79-119

Altonji J, Bloom E, Meghir C (2012) Heterogeneity in Human Capital Investments: High School Curriculum, College Major and Careers., NBER Working Paper No. 17985

Appelbaum E, Bernhardt A, Murnane R (eds) (2003) Low-Wage America. Russell Sage, New York

Aspen Institute (2003) Growing Together or Growing Apart. Domestic Strategies Group, Washington DC

Autor D (2010) The Polarization of Job Market Opportunities in the US. Center for American Progress, Washington DC

Autor D, Katz L, Kearne M (2008) The Polarization of the U.S. Labor Market. National Bureau of Economic Research (NBER) Working Paper, Cambridge

Autor D, Handel M (2009) Putting Tasks to the Test: Human Capital, Job Tasks and Wages. NBER Working Papers, 15116

Barnow B, Smith J (2004) Performance Management of US Job Training Programs. In: O'Leary C et al (eds) Job Training Policy in the United States. W.E. Upjohn Institute for Employment Research, Kalamazoo Ml

Bartik TJ (2010) Bringing Jobs to People: How Federal Policy Can Target Job Creation for Economically Distressed Areas. In: The Hamilton Project, Discussion Paper (October). Brookings Institution, Washington

Bartik TJ (2009) The Revitalization of Older Industrial Cities: A Review Essay of "Retooling for Growth"," Growth and Change, Gatton College of Business and Economics, University of Kentucky. 40(1):1-29

Bassi L, Ludwig J (2000) School-to-Work Policies in the United States: A Multi-Firm Case Study of Training, Benefits and Costs. Industrial and Labor Relations Review 53, No. 2

Besharov D, Cottingham P (eds) (2011) The Workforce Investment Act: Implementation Experiences and Evaluation Findings. W.E. Upjohn Institute for Employment Research, Kalamazoo MI

Bloom H, Orr L, Bell S, Cave G, Doolittle F, Lin W, Bos J (1997) The Benefits and Costs of JTPA Title II-A Programs. J Hum Resour 32(3):549-76

Bloom N, Van Reenen J (2010) Why Do Management Practices Differ Across Firms and Countries. J Econ Perspect 23, No. 1

Brock T (2010) Young Adults and Higher Education: Barriers and Breakthroughs to Success. The Future of Children 20:1.109-32

Bound J, Lovenheim M, Turner S (2009) Why Have College Completion Rates Declined? An Analysis of Changing Student Preparation and Collegiate Resources., , NBER Working Paper No. 15566

Card D, Dinardo J (2007) The Impact of Technological Change on Low-Wage Workers: A Review. In: Blank R, Danziger S, Schoeni R (eds) Working and Poor: How Economic and Policy Changes are Affecting Low-Wage Workers. Russell Sage, New York

Carnevale A, Smith N, Melton M (2011) STEM: Science, Technology. Georgetown University, Engineering and Mathematics. Center on Education and the Workforce

Center on Best Practices (2009) State Sector Strategies: Regional Solutions to Worker and Employer Needs. National Governors' Association, Washington DC

Center for Education Policy (2012) Student Motivation: An Overlooked Piece of School Reform., Washington

Complete College America (2012) Time is the Enemy. National Governors Association, Washington DC

Conway M, Blair A, Helmer M (2012) Courses to Employment: Partnering to Create Paths to Education and Careers. Aspen Institute, Washington DC 
Decision Information Resources Inc (2008) Youth Opportunity Grant Initiative: Executive Summary., Houston Edelman P et al (2011) State Workforce Policy: Recent Innovations and an Uncertain Future. National Skills Coalition, Washington DC

Furchtgott-Roth D, Jacobson L, Mokher C (2009) Strengthening Community College's Influence on Economic Mobility. Economic Mobility Project Pew Charitable Trusts, Washington

Goldin C, Katz L (2008) The Race Between Education and Technology. Harvard University Press, Cambridge MA

Hanushek E, Woessman L, Zhang L (2011) General Education, Vocational Education and Labor Market Outcomes Over the Life Cycle. National Bureau of Economic Research Working Paper No. 17504

Haskins R, Holzer H, Lerman R (2009) Promoting Economic Mobility by Increasing Postsecondary Education. Economic Mobility Project Pew Charitable Trusts, Washington

Heckman J, Lafontaine P (2007) The American High School Graduation Rate: Trends and Levels. NBER Working Paper

Heinrich C, Mueser P, Troske K, SeongJeon K, Kahvecioglu D (2009) New Estimates of Public Employment and Training Program Net Impacts: A Nonexperimental Evaluation of the Workforce Investment Act Programs. IZA Discussion Paper No. 4569

Heinrich C, Holzer H (2011) Improving Education and Employment for Disadvantaged Young Men: Proven and Promising Strategies. Annals of the Academy of Political and Social Sciences

Heinrich C, King C (2010) How Effective are Workforce Development Programs? Implications for US Workforce Policy in 2010 and Beyond." Prepared for conference on Workforce Policy. Ray Marshall Center, University of Texas at Austin

Hirsch B (2008) Sluggish Institutions in a Dynamic World: Can Unions and Industrial Competition Coexist? J Econ Perspect 22(1):153-176

Hoffman N (2011) Schooling in the Workplace: How Six of the World's Best Vocational Education Systems Prepare Young People for Jobs and Life. Jobs for the Future, Boston

Hollenbeck K (2008) Is There a Role for Public Support of Incumbent Worker Training Programs? W.E. Upjohn Institute for Employment Research Working Paper

Holzer H (2010) Is the Middle of the Labor Market Disappearing? Comments on the Polarization Hypothesis. Center for American Progress, Washington

Holzer H (2011) Raising Job Quality and Worker Skills in the US: Creating More Effective Education and Workforce Systems in the States. The Hamilton Project Brookings Institution, Washington

Holzer H (2013) Going, Going. . .Gone? The Evolution of Workforce Development Programs for the Poor since the War on Poverty. In: Bailey M, Danziger S (eds) The Legacy of the War on Poverty. Russell Sage Foundation, New York, forthcoming

Holzer H, Block R, Cheatam M, Knott J (1993) Are Training Subsidies for Firms Effective? The Michigan Experience. Industrial and Labor Relations Review 46(4)

Holzer H, Lane J, Rosenblum D, Andersson F (2011) Where are All the Good Jobs Going? What National and Local Job Quality and Dynamics Mean for US Workers. Russell Sage, New York

Holzer H, Lerman R (2007) America's Forgotten Middle-Skill Jobs: Education and Training Requirements for the Next Decade and Beyond. The Workforce Alliance, Washington DC

Holzer H, Nightingale D (2009) Strong Students, Strong Workers: Models for Student Success through Workforce Development and Community College Partnerships. Center for American Progress, Washington DC

Imbens G, Wooldridge J (2009) Recent Developments in the Econometrics of Program Evaluation. J Econ Lit 47(1):5-86

Jacobson L, Mokher C (2009) Pathways to Boosting the Earnings of Low-Income Workers. Working Paper, CNA, Washington DC

Jaimovich N, Siu H (2012) The Trend is the Cycle: Job Polarization and Jobless Recoveries. NBER Working Paper Langdon D, McKittrick G, Beede D, Kahn B, Doms M (2012) STEM: Good Jobs Now and for the Future. Economics and Statistics Administration, US Department of Commerce

Kemple J (2008) Career Academies: Long-Term Impacts on Labor Market Outcomes, Educational Attainment, and Transitions to Adulthood. MDRC, New York

Kemple J, Rouse C (2009) America's high Schools: Introducing the Issue. The Future of Children 19, No. 1

Lemieux T (2006) Increasing Residual Wage Inequality: Composition Effects, Noisy Data, or Rising Demand for Skill? Am Econ Rev 96(3):461-498

Lerman R (2010) Apprenticeship in the United States: Patterns of Governance and Recent Developments. In: E S, Felix R (eds) Rediscovering Apprenticeship. Research Findings of the International Network on Innovative Apprenticeship (INAP). Springer

Lerman R (2007) Career-Focused Training for Youth. In: Holzer H, Nightingale D (eds) Reshaping the American Workforce for a Changing Economy. Urban Institute Press, Washington DC

Lerman R et al (2004) The Scope of Employer-Provided Training in the US: Who, What, Where and How Much. In: O'Leary C et al (eds) Job Training Policy in the United States. W.E. Upjohn Institute for Employment Research

Long BT (2010) Grading Higher Education: Giving Consumers the Information They Need. The Hamilton Project The Brookings Institution, Washington

Maguire S et al (2010) Tuning In To Local Labor Markets: Findings from the Sectoral Employment Impact Study. PPV, Philadelphia

Malamud O, Pop-Eleches C (2010) General Education and Vocational Education: Evidence from an Economy in Transition. Review of Economics and Statistics 92(1):43-60

McGahey R, Vey J (eds) (2008) Retooling for Growth: Building a 21 ${ }^{\text {st }}$ Century Economy in America's Older Industrial Areas. The Brookings Institution, Washington DC

Miller C, Bos J, Porter K, Tseng F, Abe Y (2005) The Challenge of Repeating Success in a Changing World: Final Report on the Center for Employment Training Replication Sites. MDRC, New York

Millimet D, Smith J, Vytlacil E (2007) Modeling and Evaluating Treatment Effects in Econometrics. Advances in Econometrics. 21. Emerald Group Publishing Limited, United Kingdom

Mishel L et al (2010) State of Working America. Economic Policy Institute, Washington DC

Neumark D (2007) Improving School-to-Work Transitions. Russell Sage, New York 
Osterman P, Shulman B (2011) Good Jobs America. Russell Sage, New York

Reed D, Liu A, Kleinman R, Mastri A, Reed D, Sattar S, Ziegler J (2012) An Effectiveness Assessment and Cost-Benefit Analysis of Registered Apprenticeship in 10 States. Mathematica Policy Research, Princeton

Roder A, Elliott M (2011) A Promising Start: Year Up's Initial Impacts on Earnings of Young Adults. Economic Mobility Corporation, New York

Rosenbaum J (2001) Beyond College for All. Russell Sage, New York

Rutschow E et al (2011) Turning the Tide: Five Years of Achieving the Dream in Community Colleges. MDRC, New York Ryan P (2001) The School to Work Transition: A Cross-National Perspective. J Econ Lit 39(1):34-92

Silverberg M et al (2004) National Assessment of Vocational Education: Final Report to Congress. US Department of Education

Stinebrickner R, Stinebrickner T (2003) Working During School and Academic Performance. J Labor Econ 21(2):473-91 Symonds W, Ferguson R, Schwartz R (2011) Pathways to Prosperity. Harvard University, Graduate School of Education Zeidenberg M et al (2010) Educational Outcomes of I-BEST: New Evidence of Effectiveness. Columbia University, Community College Research Center

doi:10.1186/2193-9004-1-5

Cite this article as: Holzer: Good workers for good jobs: improving education and workforce systems in the US. IZA Journal of Labor Policy 2012 1:5.

\section{Submit your manuscript to a SpringerOpen ${ }^{\circ}$ journal and benefit from:}

- Convenient online submission

Rigorous peer review

- Immediate publication on acceptance

- Open access: articles freely available online

- High visibility within the field

- Retaining the copyright to your article

Submit your next manuscript at $\gg$ springeropen.com 